\title{
Community development through Islamic microfinance approach: The experience of Daarut Tauhid Peduli Bandung, Indonesia
}

\author{
Ela Nurhayati ${ }^{*}$, Agus Ahmad Safei ${ }^{2}$, Aya Ono ${ }^{3}$ \\ 1 Victoria University Melbourne, Australia; e-mail: ela.nurhayati@live.vu.edu.au \\ 2 UIN Sunan Gunung Djati Bandung, Indonesia; e-mail: agus.safei@uinsgd.ac.id \\ 3 Royal Melbourne Institute of Technology, Australia; e-mail: aya.ono@rmit.edu.au \\ * Correspondence
}

Received: 2020-08-06; Accepted: 2020-12-11; Published: 2020-12-30

\begin{abstract}
The fields of zakat-based microfinance and community development are not often placed under the same theoretical lens that both aim to empower disadvantaged people. This study investigates the experiences of borrowers in the implementation of zakat-based microfinance and analyses the different driving factors they applied in their choice of the zakat-based microfinance of Daarut Tauhid Peduli in Bandung, Indonesia. It applies a community development framework, based on the five characteristics, to explore this Islamic microfinance approach as an effective community development program, which has a religious dimension. Primary data were obtained from semistructured interviews with the borrowers along with participant observation at a weekly majelis meeting, and these were triangulated with information cross-checked with the management staff of the institution. The findings demonstrate three out of five characteristics of the zakat-based microfinance approach as an effective community development program. They include characteristics in constantly maintaining power relations between borrowers and the institution, increasing capability and ability of borrowers to be more independent and empowered, and long-term duration of the program and sustainability. The findings showed that spiritual factors appear to have been an additional driving force on top of economic and non-economic factors for most borrowers choosing this particular program.
\end{abstract}

Keywords: Community Development; Islamic Microfinance; Spiritual Empowerment; Zakat; ZakatBased Microfinance.

Abstrak: Kajian tentang keuangan mikro berbasis zakat di masyarakat biasanya tidak dianalisis dalam perspektif kajian teori yang sama yang ditujukan untuk membantu pemberdayaan orangorang yang lemah secara ekonomi. Tulisan ini berusaha untuk menelaah pengalaman-pengalaman para peminjam modal dalam skema keuangan mikro berbasis zakat yakni pendayagunaan dana zakat yang dikelola oleh Daarut Tauhid Peduli di Bandung, Jawa Barat, Indonesia. Penelitian ini menggunakan kerangka community developmen untuk mengetahui keuangan mikro berbasis Islam ini dalam mengembangkan pemberdayaan masyarakat dan hubungannya dengan aspek keagamaan. Data penelitian didapat melalui wawancara semi-terstruktur dengan para peminjam modal disertai dengan observasi pertemuan mingguan (majelis) antara anggota dan staf management lembaga. Penelitian ini menunjukkan hasil bahwa terdapat beberapa karakter yang digunakan dalam menjalankan sistem keuangan mikro berbasis zakat ini dalam rangka pemberdayaan umat. Di antaranya adalah: menjaga relasi antara peminjam dan lembaga, membantu para peminjam untuk lebih mandiri dan berdaya, menjaga hubungan jangka panjang tentang program dan keberlangsungannya. Penelitian ini juga menunjukkan bahwa aspek keagamaan menjadi pendorong utama bagi para peminjam modal untuk menggunakan fasilitas lembaga keuangan mikro berbasis zakat ini. 
Kata Kunci: pemberdayaan masyarakat; keuangan mikro Islam; pemberdayaan spiritualitas; Zakat; keuangan mikro berbasis zakat.

\section{Introduction}

Community Development (CD) programs are set to contribute to ending poverty which is one of the greatest challenges of the Sustainable Development Goals (SDGs) in most developing countries including Indonesia. Sustainable and long-term funding sources and community development programs are needed to overcome this challenge. In terms of funding sources, social finance is considered to play a very important role in replacing government and donor funding for non-profit organizations in the implementation of community development programs in Indonesia and most Muslim countries. Islamic finance tools such as zakat (Islamic mandatory giving and the third pillar of Islam) is an obligation within Islam for all Muslims who meet a certain threshold to pay at least 2.5 $\%$ of their accumulated wealth or income for the benefit of people who are classified as mustahiq (deserver). Apart from zakat there also waqf (an Islamic endowment of property to be held in trust and used for a charitable or religious purpose) (Rosadi, Effendi, \& Busro, 2018), and sadaqa (charity) are considered to be the most potential social finance sources that have been used as instruments in eradicating poverty and socio-economic development in Muslim countries (Sadeq, 2002; Shaikh, Ismail, \& Mohd Shafiai, 2017) including Indonesia (Kasri, 2016; Sari, Bahari, \& Hamat, 2013). The fact that the national economic value of zakat collection in Indonesia was almost similar to 3,4\% of the Gross Domestic Product (GDP) (Pickup, Beik, \& Buana, 2018). This demonstrates that zakat is a powerful and long-term source of funding for Indonesian society that can be allocated for greater development impact through the implementation of ranging and sustainable community development programs.

Zakat as a tool of poverty reduction has been the subject of numerous studies (Ismail \& Possumah, 2013; Permono, 2005; Sudirman, 2011; Toriquddin, 2015). However, there are differing views on the distribution of zakat. Scholars such as Nurzaman (2010) argue that zakat should be disbursed consumptively through direct distribution (individual distribution), while others such as Permono (2005) and Sudirman (2011) state that zakat can be distributed to the needy through consumption programs as well as production programs. The third group of scholars such as Ismail and Posumah (2013) and Toriquddin (2015) insists that production should be prioritised in delivering zakat because it can educate the poor to use money effectively. Although a body of research highlights zakat as a tool of poverty alleviation through microfinance practice, many zakat institutions have faced obstacles in achieving sustainability and ensuring that microfinance institutions can empower and strengthen poor communities to increase their wellbeing.

No research to date has examined how best to implement effective community development programs in the zakat-based microfinance context, though the topic of program implementation has been examined in a wide range of fields. Past research indicates that when communities replicate programs, the quality of delivery can vary widely. This is because aspects of a program will be altered to match community characteristics. Thus, research is needed to identify the specific elements of evidence-based programs that are essential to program success, together with those elements that may be modified while remaining true to the intended purpose or concept underlying the model-also known as maintaining fidelity. Research is also needed to identify the types of information needed to adopt and adapt known potential programs without compromising their fidelity and successful outcomes.

Despite the wide implementation of zakat-based microfinance, improving the sustainability of the program remains the main issue within zakat institutions. Zakat-based microfinance brings not only interest-free financing but also issues related to repayment performance, capacity building for the entrepreneurs - borrowers - such as business advice, project monitoring, and evaluation. Further, spiritual factors that influence borrowers in choosing zakat-based microfinance remains unexamined. A comprehensive approach that integrates multiple perspectives, including economic, non-economic, 
and spiritual, is greatly needed to fuel more concerted effort for the achievement of Sustainable Development Goals.

This study investigates the experiences of borrowers in the implementation of zakat-based microfinance and analyses the different driving factors they applied in their choice of the zakat-based microfinance of Daarut Tauhid Peduli in Bandung, Indonesia. This research uses a method of case study, with qualitative data obtained from semi-structured interviews and triangulated by participant observation, and data were cross-checked with two management-level representatives of zakat-based microfinance of Daarut Tawhid Peduli (DT Peduli). A case study using a semi-structured interview and participant observation fits into the interpretative paradigm to understand human experiences (Chilisa \& Kawulich, 2012). This research takes place in a natural setting (in their daily life setting of respondents) where the participants make their living. In this research context, these two methods are appropriate to explain the qualitative characteristics of effective $C D$ program and nuanced motivating factors of zakat-based microfinance members of DT Peduli.

The zakat-based microfinance of DT Peduli in Bandung city, West Java, Indonesia, was chosen because it is one of the biggest zakat-based microfinance institutions in West Java with around 2,975 members (Koperasi Pemberdayaan Ummat, 2020).

In this research, 15 female borrowers of KOPMU (Koperasi Pemberdayaan Umat, Community Development-based Cooperative) members in urban and suburban areas of Bandung were asked to participate in face-to-face interviews in their house or other reasonable places such as in their outlets where they operated the businesses. Interviews lasted approximately an hour. The respondents are from 11 different majelis (group) who have been members for at least 2 years.

In this study, the researcher observed the activities during majelis meeting, as well as observed the different entrepreneurship types of each borrower of zakat-based microfinance of DT Peduli. Participant observation in the KOPMU's regular majelis meeting was carried out to allow the researcher to investigate participation dynamics, activities, and the interactions and power relations between members and mentors in the majelis meeting setting.

In addition to these two methods, to cross-check some information on the program implementation particularly on the information related to loan mechanism and the institution policy, the researcher interviewed two representatives of the institution - the Managing Director and Secretary.

\section{Zakat-based microfinance and Community Development}

The potential for zakat to be the core source of funds for community development programs requires further attention. Zakat as the third pillar of Islam is generally associated with poverty reduction by providing direct financial support for poor people's daily needs (Nurzaman, 2010). Most zakat institutions tend to distribute zakat in the form of food or cash transfers, neither of which are sustainable and only have short-term impacts for the recipients. Suprayitno, Abdul Kader, and Harun (2013) find that zakat distribution has a small impact on aggregate consumption. Thus, zakat distribution should not be limited to consumer needs, but should also include other forms of production-based programs that can continuously generate an income flow for zakat recipients (Ismail \& Shaikh, 2017). Furthermore, Sudewo (2004) highlights the problem where management and disbursement of zakat remain under the consumption scheme. In response to this problem, many scholars have suggested various ways to reduce poverty by using zakat as the main tool. As a potential tool of poverty reduction, zakat should be disbursed effectively into long-term and production-based programs to give maximum benefit to the recipients (Ismail \& Possumah, 2013; Permono, 2005; Sudirman, 2011; Toriquddin, 2015).

A production-based community development program will be more effective when the basic needs of the recipients have been fully met. Therefore, this production program is recommended to target mustahiq who are not categorised as living in extreme property (Hasan, 2016). The objectives of the program could be achieved by introducing, implementing, and supporting economic activities for the poor. The production program is prioritised in delivering zakat because it can educate the poor to use the money effectively. Alim (2015) suggests that zakat for production purposes is usually associated 
with a loan or revolving funds. A 'soft loan' (loan with no interest or below-market-rate of interest) is considered a way of contributing to their independence. The practice of 'soft loan' is the capital given is not charity; the money must be repaid, but interest-free. Therefore, this might decrease the potential dependency of mustahiq on receiving regular zakat.

When zakat is allocated for production-based programs such as microfinance, it benefits not only the recipients but also the family and the wider community. Suryanto (2018) emphasises that zakat, as part of a fundamental pillar of Islam, encourages Muslims to contribute to promoting inclusiveness, productivity, and sustainability of community development programs Wahab \& Rahim Abdul Rahman (2011) explain the types of programs that are potentially more productive and sustainable, including vocational training and improve soft skills, the provision of fixed assets and equipment to small business projects, the building of low-cost housing, and the provision of medical treatment and health care.

Furthermore, production-based zakat distribution can be more effective when a zakat institution collaborates with a microfinance institution. Islamic microfinance utilises funds from zakat, and the model is called zakat-based microfinance. The model combines Islamic microfinance with two traditional Islamic tools of poverty alleviation - zakat and waqf (charitable trust) to mandate less debt burden on poor borrowers (Hassan \& Ashraf, 2010; Ismail \& Shaikh, 2017), incorporating the weakness of a microfinance institution - lack of funds - and the advantages of zakat - availability of funds (Ismail \& Possumah, 2013). The qualitative research of Suryanto (2018) also demonstrated the significant potential of zakat- based microfinance in reducing poverty. It minimises indebtedness and helps the poor to be more productive and secure in maintaining their businesses. Zakat-based microfinance facilitates both financial (soft loans) and capacity building support for recipients, including business mentoring programs.

In this sense, zakat-based microfinance can be an appropriate model for implementing effective community development programs in Muslim countries such as Indonesia. According to Yumna and Clarke (2011), zakat-based microfinance can be used as a strategy to distribute zakat for better outcomes in alleviating poverty and improving the quality of life for mustahiq. community development programs that involve zakat-based microfinance are designed to encourage borrowers to be able to own a business independently and offer much-needed funds for the poor through workable schemes that give them a real chance of lifting themselves out of poverty (Minako Sakai, 2014; Suryanto, 2018). For example, zakat-based microfinance achieves community welfare by providing start-up capital to poor people wishing to start their businesses, by offering free health care services or scholarships to the needy, or by organising workshops and study groups to increase knowledge about Islamic business concepts and to teach financial and accounting skills (M. Sakai, 2008). Zakat-based microfinance can therefore be regarded as a potential community development program to empower the economy of the borrowers (mustahiq).

\section{Sustainability in Islamic microfinance institutions}

There are several issues related to the sustainability of the practice of Islamic Microfinance Institutions (IMFs). The sustainability issue is attributed to both financial performance and social impact. Financial performance is critical to cover their operating costs and grow as viable institutions in running microcredit and operational activities (Cull, Demirgu"ç-Kunt, \& Morduch, 2007; Navajas, Schreiner, Meyer, Gonzalez-Vega, \& Rodriguez-Meza, 2000). In the same vein, it is also integral to reach the unbackable poor to maximise the social impact (Ahlin \& Jiang, 2008; Louis, Seret, \& Baesens, 2013; Navajas et al., 2000). For this reason, Microfinance institutions (MFIs) have to pursue social performance in long-term operations so that they can contribute for greater positive impacts on the poor, in addition to pursuing financial performance (Quayes, 2012). Therefore, the provision of education and training, better coordination and networking, and technical assistance through waqf and zakat funds is necessary for the effectiveness and sustainability of Islamic microfinance (Rashidah \& Siti Balqis \& Faisal, 2013). 
However, in addition to financial and social aspects, a spiritual aspect should also be considered in addressing the sustainability of Islamic Microfinance Institutions (IMFIs). Previous research on IMFI sustainability generally viewed the financial, social, and spiritual aspects as segregated elements. A study by Wediawati et al. (2018) of 98 IMFIs in Indonesia using a structured questionnaire based on a 5-point Likert scale found that financial, social, and spiritual intermediation has a positive significant effect on the sustainability of IMFIs in Indonesia. These results also showed that the sustainability problem for IMFIs can be overcome by applying a holistic approach (financial, social, and spiritual). Yet, it is notable that the authors did not triangulate these interviews with participant observation. A Likert scale was not chosen for my research, which was much smaller in scale (only one microfinance institution).

\section{Motivating factors influencing borrowers in choosing Islamic microfinance institutions}

Indonesia has a broad diversity of both conventional and Islamic microfinance models. According to Masyita and Ahmed (2013), IMFIs grew slowly in Indonesia compared to conventional Microfinance Institutions (MFIs). Therefore, identifying driven factors of borrowers in choosing microfinance institutions become important to improve and develop quality service and management of IMFIs. A survey study using multistage cluster sampling with 581 clients of MFIs and IMFIs in Bandung, Indonesia by Masyita and Ahmed (2013) found that a conventional MFI tends to be preferred most by the clients, because of economic and non-economic factors. In terms of economic factors, the respondents revealed that low interest, low collateral and amount size of the loan is the main driven factors in choosing both MFIs or IMFIs. Besides, non-economic factors mostly related to services such as ease and speed in the process of a loan application and geographic proximity of the institutions to their residential areas. Those two non-economic factors also influenced clients in deciding microfinance institutions (Masyita \& Ahmed, 2013). Moreover, other economic and non-economic factors influencing clients in choosing microfinance institution (both conventional and Islamic) is also demonstrated in the study by Obaidullah and Khan (2008) and Dupas (2013).

Economic factors such as the cost of financial services and interest rate and non-economic factors such as flexibility and timeliness were prioritised by clients in choosing the institutions (Obaidullah \& Khan, 2008). Another factor influencing clients in choosing IMFIs is the spiritual or religious aspect. In some studies, the term spiritual and religious are interchangeable (Dupas \& Robinson, 2013; Masyita \& Ahmed, 2013; Obaidullah \& Khan, 2008). In the study of Masyita and Ahmed (2013) most clients answered that they were choosing IMFIs because the institutions offered Islamic products. The spirituals aspects such as peace, confidence, and prohibition of riba' were the three main reasons acknowledged by the clients (Masyita \& Ahmed, 2013). Where when respondents were asked about their preferences towards their choice for Islamic products or conventional, the majority preferred IMFIs. However, in reality, the economic and non-economic factors became dominant factors influencing clients in choosing both MFIs and IMFIs. In other words, that spiritual or religious aspects such as the prohibition of riba' were not the main reasons for selecting an IMFIs. The findings in this paper suggest that to attract clients to Islamic microfinance, the IMFIs have to provide the same level and quality of products and services as conventional ones despite their faith background.

\section{Characteristics of effective community development programs}

When it comes to assessing the effectiveness of community development programs, certain characteristics need to be evaluated. Labonte (1997) explains the identification of common problems and issues based on local needs, cultures, and conditions to ensure sustainability in community development programs. Besides, ownership - planning and implementing strategies to mitigate and solve their challenges is an integral element. Labonte $(1997$, p. 97) also indicates the following five characteristics as necessary to implement effective community development programs:

1. Power relations between the agency and community members need to be constantly negotiated. 
2. Problems or issues are identified by the community and defined in a way that advances the shared interests of the community and the agency.

3. The program is capable of long-term implementation and sustainability.

4. The desired outcome is to increase the capacity and ability of the members of the community to be more independent and empowered.

5. The desired long-term outcomes should include the wider scope of a change either at the neighbourhood or community level.

These five 'Labontean' characteristics are the strategic objectives of community development used globally, to empower local communities, develop effective partnerships, work as multi- agencies, become learning organizations, improve the life and wellbeing of the community and, of course, create a sustainable community (Isidiho \& Sabran, 2016). Therefore, community development is embodied in the organization's attempt to engage in social engineering in economically disadvantaged communities to reduce poverty and increasing wellbeing. Below describes each of these important characteristics of effective community development programs.

\section{Community development and spirituality}

This research delves into an Islamic-based institution rooted in Islamic law in the implementation of the program. However, under the influence of enlightenment and modernity, contemporary societies are essentially secular, and this has left significantly little room for notions of sacred or spiritual values. According to Ife (2013), a community development practitioner and academic laments that contemporary society has effectively denied one of the most important aspects of human existence spirituality -, which for many people (especially in indigenous and other religiously dominant societies) is central to their lives and the experience of the community. Spirituality dwells within every culture and every geographical community because as people search for meaning, spirituality becomes embedded in their ways of life (Fabry, 1980); it informs their ethics and desires. In my research, Indonesian spirituality is fostered from tradition as well as from the Islam religion, even though politically Indonesia is a secular country where there is a clear separation of powers.

A spiritual aspect closely aligns with the values and principles that underpin community development. This aspect is an essential component of the approach to community development along with social, economic, political, cultural, environmental, personal, and survival (Ife, 2013). The underpinning values and principles of community development and spirituality are the connection of the individual to the collective, acknowledging that the wellbeing of the individual influences and is influenced by the wellbeing of the community (Chile \& Simpson, 2004). Ife (2013) further argues that there is a strong need for community development to incorporate notions of spiritual development because community development is concerned with the full range of human experience.

Moreover, there must be an equilibrium of the development process and development outcomes. They must be in harmony, socially just, and sustainable, and are achieved with respect for diversity, shared knowledge, and a re-imagining of the future. Chile and Simpson (2004) also recognize the central importance of spirituality in community development. They state that 'spirituality in community development seeks to remove those things that suppress the expression of individual and collective empowerment' (Chile \& Simpson, 2004, p. 324), intimating that the attainment of such empowerment is intrinsically guided by spirituality. In terms of spirituality and community development, Islam has developed and designed some instruments that are used as tools in the work of community development. As-Siba'i (1968) and Hawwa (2004) mention that the institution of zakat is one of the critical instruments of community development.

\section{Community Development of zakat-based microfinance: The experience of Daarut Tauhid Peduli}


The main findings from this study demonstrated that the zakat-based microfinance of Daarut Tauhid Peduli has implemented an effective community development program about three of five characteristics of an effective community development program as defined by Labonte. First, power relations between borrowers and the mentors of KOPMU are well-maintained and constantly negotiated. In the implementation of the zakat-based microfinance of Daarut Tauhid Peduli, power relations demonstrate the horizontal relationship of women borrowers with the management of KOPMU, particularly mentors who are mostly male fieldworkers. Based on interview results and participant observations during a majelis meeting, it appeared there were no gendered power relations embedded in the microfinance practices and socio-cultural gender norms; thus, the male mentors did not seem to be dominant compared to the female borrowers. In the practices of KOPMU, this research demonstrates that there are no perceived social and economic inequalities created by the institution.

Second, concerning the duration of the program and sustainability, Daarut Tauhid Peduli has implemented a long-term program because they have a sustainable source of funding from zakat. The average membership period of borrowers was eight years, with the longest one reaching 15 years. Most borrowers revealed that they experienced an increase in household income after three to five years as a member of KOPMU, and the repayment performance of respondents reached $100 \%$. Therefore, they have accessed loans more than three times in less than five years. However, the general repayment rate of the institution ( $86 \%)$ is lower than the national repayment rate $(92 \%)$. The finding for this characteristic indicates that the institution implemented the zakat-based microfinance in a long-term period with 6 years average membership of the borrowers. When it comes to the sustainability of the institution, the repayment rate is $100 \%$. The sustainability of borrowers is also achieved by the increase of their household income by the majority of borrowers.

Third, when it comes to increasing the capacity and ability of the targeted community, the majelis meeting approach was considered effective in building the 'assets' of borrowers. The vast majority of respondents acknowledged that they experienced an increase in skills, knowledge, friendship, and networking by actively being involved in the regular majelis meeting. The findings also highlighted that for KOPMU to be fully categorized as an effective community development program, it should focus on improving the two remaining characteristics of Labonte that were not addressed. These include the second characteristic, which is taking a more bottom-up and participatory approach to issues, and the last characteristic, which is desired long-term outcomes in terms of the transformation of borrowers from mustahiq to muzzaki (the party who are obliged to pay zakat).

Two other characteristics of participation and long-term outcomes seem to be neglected since the research findings show that the borrowers take a lesser role in the design of the microfinance program, the management of KOPMU explained that they were planned and developed the whole program, including designing the training, workshops, and other related activities for the members without any involvement of the members. They confirmed that borrowers were only involved during the training as participants; they were not involved in planning, monitoring, and following up after training. In terms of long-term outcomes in the context of the transformation of mustahiq into muzzaki, this was hard to measure because the institution has not recorded and monitored officially the progress of borrowers who have already transformed to muzzaki. Therefore, the researcher was not able to identify and define the scope of benefits of the program to the wider community.

When it comes to motivating factors of urban and suburban members in choosing microfinance institution, this table below shows the summary of underlying factors in choosing KOPMU as a financial service (table 1);

Table 1 Summary of underlying factors in choosing KOPMU as a financial service

Motivating Factors Urban Suburban




\begin{tabular}{|c|c|c|}
\hline Economic & $\begin{array}{l}\text { interest-free } \\
\text { no collateral }\end{array}$ & $\begin{array}{l}\text { interest-free } \\
\text { no collateral } \\
\text { loan amount }\end{array}$ \\
\hline Non-economic & $\begin{array}{l}\text { repayment flexibility } \\
\text { quality service } \\
\text { friend's suggestion }\end{array}$ & $\begin{array}{c}\text { easy and simple requirements } \\
\text { familiarity } \\
\text { speed } \\
\text { proximity } \\
\text { didn't know other institutions }\end{array}$ \\
\hline Spiritual & $\begin{array}{c}\text { Islamic teaching } \\
\text { silaturahmi } \\
\text { barakah } \\
\text { Sharia-based institution } \\
\text { Peaceful }\end{array}$ & $\begin{array}{c}\text { Islamic teaching } \\
\text { silaturahmi } \\
\text { Halal (Sharia-based institution) }\end{array}$ \\
\hline
\end{tabular}

Table 1 shows the categorized motivating factors of borrowers in choosing the zakat-based microfinance KOPMU of Daarut Tauhid Peduli. The first two categories (economic and non-economic) and their reasons were also found in previous studies by Masyita \& Ahmed (2013) and Obaidullah \& Khan (2008). It would appear from the preference of both urban and suburban respondents in choosing the financial services of KOPMU that it is not only based on economic and non-economic factors, but also a spiritual aspect. The last aspect is a new finding from this research and a new addition to the literature.

The spiritual aspects are harnessed through the weekly majelis meeting, the impact of which is to internalize the Islamic moral values in the consciousness of the entrepreneur (akhlaq) and to encourage honesty, discipline, passion, perseverance, patience, piety, social responsibility, and the awakening of consciousness, or the turning of bad attitudes (bad akhlaq) into a good manner. The religious dimension is treated as a goal equal to the actual loan provided.

KOPMU program does not fully adopt the bottom-up approach and the current level of participation by borrowers' limit decentralized decision making

The KOPMU Daarut Tauhid Peduli program adopts a combination approach - both bottom-up and top-down. Participation of borrowers in the program implementation is categorized as having a limited decentralization of decision making (Dooris \& Heritage, 2013). Some training topics provided by KOPMU neither met the needs nor supported the businesses of borrowers because the institution had limited expertise in providing business-specific training. The finding indicates that the institution was not able to accommodate the borrowers' inputs/feedback due to the lack of organizational capacity, which deters participation of borrowers in certain training and other capacity-building activities.

Accordingly, a fully bottom-up approach is not possible to be employed by KOPMU Daarut Tauhid Peduli due to the lack of management capacity. Theoretically, an effective community development program empowers communities to change their condition, and this can happen if the community is actively involved in every process of the program (planning, implementation, monitoring, and evaluation) (Isidiho \& Sabran, 2016; Kenny \& Connors, 2016). Nevertheless, in the current KOPMU program, the involvement of borrowers is still partial and limited in the planning of programs, such as their involvement in identifying, defining, and designing the type of businesses. Although Daarut Tauhid Peduli provides a feedback loop, including monitoring and evaluation tools, to encourage a bottom-up approach, follow-up on the feedback instruments remains a challenge for the institution.

This research findings reveal that borrowers demonstrated passive participation in attending training because the training did not meet their business needs despite their active participation in the 
weekly majelis meeting. A bottom-up approach is associated with the level of participation of communities. Isidiho \& Sabran (2016) argue that a bottom-up approach can be measured through the participation levels of borrowers. All the activities including training topics and activities during majelis meetings have been decided and organised by the management level of KOPMU. This is because most respondents are older women who are not used to giving opinions in public, either because of their educational background or cultural factors.

In community development, the community should have full involvement and leadership in the entire program implementation process, including planning, developing, delivering, and evaluating community actions or initiatives. Dooris and Heritage (2013) emphasize that participation must not be tokenistic; community members must be participating in a way that is meaningful to them and to the community development program itself. In the case of the KOPMU program, the borrowers still have limited decision-making power to access training on topics that meet a specific business need. As a result, some borrowers have a low participation level because the training is outside their interests. Some respondents justified that they had never attended a training meeting because the topic of training did not meet their needs.

It could be argued that to meet the members' needs, KOPMU should identify, assess, and adjust training programs based on how useful and applicable training would be in improving members' businesses. It is very important for the institution to review the purpose of the training program and identify learning goals and outcomes, as well as to determine who the participants will be since members of KOPMU have different types of businesses. Thus, the management levels of KOPMU should collect data on targeted borrowers for each training topic or capacity-building program. This would be very beneficial for two main reasons. First, it would allow KOPMU to refocus its efforts and keep the big picture in mind. Second, it would give the participants an idea of where the training is headed and what would be expected of them at the end of the process.

Based on this research finding, the implementation of the zakat-based microfinance of Daarut Tauhid Peduli might adopt a combined approach rather than solely a bottom-up approach. This also draws on a previous study on the evaluation of bottom-up and top-down approaches to community development programs, where adopting a combined approach is more applicable in more diverse and larger communities (Isidiho \& Sabran, 2016).

Furthermore, a combined approach to community development enables the operators to blend the top-down and the bottom-up; these two approaches enable a realignment, and as a result, complement each other to achieve the goals of community development that involve both the top (the agency) and the bottom (the borrowers) -where neither of them complains. This way, some silent factors such as cultures or norms that are prevalent in the life of rural communities must be considered by the top and embedded in the design and implementation process.

The application of the combined approach may initially create a class difference and exhibition of dominance by some members, but once the class difference is neutralized through the implementation, the project would bring a co-operative, horizontal development that is sustainable and would benefit the wider society (Isidiho \& Sabran, 2016). A combined approach would bring the added advantage of eliminating the domination of program implementation by management levels, who possess stumbling blocks and can shield meaningful development from reaching the borrowers' domain.

\section{Majelis meeting setting is being the core of the whole microfinance program of KOPMU}

A majelis meeting setting is a substantial and core activity within the whole program that maintains power relations between borrowers and mentors, promotes sustainability, and increases the capacity and ability of the borrowers. They have adopted the principles of asset-based community development (ABCD) through the majelis meeting, by ensuring more power to the borrowers such as selfdetermination of business types and identifying self- assets.

These research findings outlined that the majelis setting is considered an effective community development program for three reasons. Firstly, the third characteristic of effective community development programs is long-term sustainability. The findings show that the majelis setting is the main 
reason why borrowers stay with the IMFI, even though they no longer require loans. The average length of membership is six to eight years, with the longest membership 15 years and the shortest two years. Nearly a quarter - four out of 15 respondents - are still active members of KOPMU, regularly involved in a weekly majelis meeting. The longest-term respondent admitted that the majelis meeting is the main reason for her continuing actively in the KOPMU program because of religious or spiritual gains.

Secondly, in terms of sustainability, the majelis setting approach adopted in the KOPMU program has a positive impact on a high repayment rate, which can directly influence the sustainability of the IMFI program. This good repayment performance has a direct impact on the sustainability of the institution. The findings indicate that the majelis meeting contributed to the higher repayment rate to achieve the sustainability of the institution. This research on the majelis setting confirms the study by Sanrego (2013) which indicated that Islamic microfinance-based groups can ensure that their members can obtain financial services and can repay their loan on time due to strong social capital built-in group settings with spiritual aspects. The data from interviews revealed that all 15 members had a good repayment performance and were, therefore, able to re-access loans more than two times. This finding also confirms that the majelis meeting plays an important role in the repayment behaviour of borrowers. Loan repayment performance of borrowers of the zakat-based microfinance of DT Peduli is very much affected by the existing social capital which is embedded in the majelis meeting setting. The role of majelis meetings in this context is a positive means of capacity building in the form of building and fostering social relationships of borrowers.

Second, concerning duration of the program and sustainability, Daarut Tauhid Peduli has implemented a long-term program because they have a sustainable source of funding from zakat. The average membership period of borrowers was eight years, with the longest one reaching 15 years. Most borrowers revealed that they experienced an increase in household income after three to five years as a member of KOPMU, and the repayment performance of respondents reached $100 \%$. Therefore, they have accessed loans more than three times in less than five years. However, the general repayment rate of the institution $(86 \%)$ is lower than the national repayment rate $(92 \%)$. The finding for this characteristic indicates that the institution implemented the zakat-based microfinance in a long-term period with 6 years average membership of the borrowers. When it comes to the sustainability of the institution, the repayment rate is $100 \%$. The sustainability of borrowers is also achieved by the increase of their household income by the majority of borrowers.

A good repayment rate is a good achievement for an institution to reach financial sustainability. However, in terms of sustainability for borrowers, the institution should have a strategic time frame and plan to mobilise and empower communities to not depend on loans and the institution's programs. For this to happen, Ife (2009) emphasizes that the institution must be able to drive the program with flexibility and adapt the capacity of the targeted community, and a willingness to look at likely futures and the challenges that they will pose with effective strategic planning based on local contexts. For example, the institution should strive to achieve and map out the necessary steps and activities needed to be successful and achieve sustainability both for the institution and the targeted community. KOPMU can have a strategic plan for 10 years or more because they have a long- term financial source for zakat.

The majelis setting has a positive impact on increasing the capacity and ability of borrowers as characterised by effective community development programs. In the context of KOPMU, the majelis setting aims to build social capital among borrowers. A majelis meeting also targets borrowers to increase the frequency of obligatory and voluntary worship. From the interviews, the respondents acknowledged that they gained many benefits in increasing their capability and abilities through the majelis meeting. The borrowers revealed that they gained a lot of benefits from KOPMU. This finding was previously indicated by Kenny \& Connors (2016), who said that an effective community development program is characterised by giving direct benefits to the targeted community. They further assert that beneficiaries directly involved in community development initiatives may benefit from increases in skills, knowledge, empowerment, and self-efficacy, and experience enhanced social inclusion and community connectedness (Kenny \& Connors, 2016). 
The majelis setting is considered an important asset both for borrowers and the institutions. By focusing on its 'assets' within the majelis setting, the community as a whole will see its positive aspects (such as a mentoring program and the many skills of its members that can be identified) and can then work on further solidifying these assets. Concentrating on community assets will create a snowball effect that will influence other areas within a community such as its needs and problems. Kretzmann \& McKnight (1996) and Haines (2009) confirm that by focusing on the assets of the community, the implementation of community development programs can be more effective when both the community and the institution are more focused on the successes and small triumphs than on the community's needs, deficiencies, and problems. However, Haines (2009) emphasizes that this process does not ignore the problems or issues within a community, but focuses first on its strengths and small triumphs to provide a positive perspective of the community rather than a discouraging one.

In the context of zakat-based microfinance focusing on member assets, for instance, this approach would focus on existing small businesses and their success, rather than on starting a new business without having experience and expertise. According to respondents, they have been starting their businesses long before they accessed loans from KOPMU. Kretzmann \& McKnight (1996) confirm that outside resources (loans from KOPMU) will be much more effectively used if the local community is itself fully mobilized and invested (in full control of the borrowers in defining and designing their businesses).

\section{Desired long-term outcomes in a form of transformation of mustahiq to muzzaki}

The desired long-term outcomes of zakat-based microfinance as a community development program was observed where eight out of 15 respondents have transformed from mustahiq to muzzaki and can give wider benefits to society. This illustrates the potential broader impact on society as a result of their transformation into muzzaki who are now in the position of support providers, not support recipients. However, the institution did not have any access data on the transformation of mustahiq to muzzaki. They are planning to collect the data on borrowers' transformation because it is their goal for borrowers categorized as mustahiq to become muzzaki.

On reducing poverty, Islamic Microfinance Institutions (IMFs) are focused on maximizing benefits for the wider community through maintaining financial sustainability to enable more poor people to have access to these services. This finding is similar to ROSCA (Rotating Savings and Credit Association). ROSCA has demonstrated that informal finance remains very relevant in enhancing income for poor households and community development in developing countries and has suggested extending credit more widely to poor communities (Kabuya, 2015). In the context of zakat-based microfinance where the source of institution funding comes from zakat, considering the sustainability in a way borrowers can pay zakat is also very important. This will ensure not only increasing the household income but also further encouraging borrowers to be able to pay zakat.

\section{Long-term period and effective community development program}

This research findings show that although $87 \%$ of respondents indicated experiencing an increase in household income, only 8 out of 15 respondents were able to pay zakat regularly. It means that the increasing household income will not always be associated with the eligibility of borrowers to pay zakat. Some respondents admitted that they are not paying zakat because their annual total income is still below nisab. Apart from that, KOPMU did not record information on the transformation of borrowers who already met the income threshold to pay zakat. Therefore, officially, long-term outcomes of the KOPMU program are not measured.

The findings show that a long-term period of program implementation is not solely a characteristic for effective community development programs but also strategic planning. Strategic planning in building community members' capacity to be independent and able to control their 'assets' and resources is a far more important process. The findings showed that the zakat-based microfinance of Daarut Tauhid Peduli has no limit to the period of membership, which means the implementation of this program can run for a long-term period. The longest membership of respondents is 15 years. 
Although the membership period has a positive impact on increasing household income, it is no associated with the transformation of mustahiq to muzzaki. This means that the long-term period of the program, without good strategic planning including clear outcomes, does not impact the desired longterm outcomes of giving benefits to the wider community. Furthermore, engagement and planning can take a year or more, and it can take several years to build the capacity of community members to lead a project and ensure sustainable results. Therefore, to meet this characteristic of an effective community development program, KOPMU Da'arut Tauhid Peduli should develop strategic planning which pictures the current and future needs of the targeted communities (Ife, 2009).

On reducing poverty, IMFIs are focused on maximizing benefits for the wider community through maintaining financial sustainability to enable more poor people to have access to these services. This finding is similar to ROSCA (Rotating Savings and Credit Association). ROSCA has demonstrated that informal finance remains very relevant in enhancing income for poor households and community development in developing countries and has suggested extending credit more widely to poor communities (Kabuya, 2015). In the context of zakat-based microfinance where the source of institution funding comes from zakat, considering the sustainability in a way borrowers can pay zakat is also very important. This will ensure not only increasing the household income but also further encouraging borrowers to be able to pay zakat.

\section{A spiritual aspect plays an important role in the implementation of the KOPMU program}

The spiritual aspect was the main reason for many borrowers choosing KOPMU Daarut Tauhid Peduli. This has a positive influence on repayment performance and an awareness by borrowers to pay zakat. This finding indicates that spiritual aspects such as halal, sharia, barakah, and Islamic knowledge were the main motivating factors of borrowers in choosing KOPMU DT over other institutions.

As noted in the scheme of KOPMU, attending majelis meetings is compulsory, and Islamic lectures are an important part of the meetings. During majelis meetings, the mentors teach Islamic concepts and laws to the borrowers to share the basic notions and principles of Islam and encourage them to apply this knowledge to daily life. Riwajanti (2014) also confirms that it is necessary to educate members to improve their understanding of Islamic concepts to promote the values of Islam to the wider society. It is because as a Sharia-based financial institution, the purpose of Islamic Microfinance Institutions (IMFIs) must be consistent with the objective of Sharia (maqasid syariah). This aim leads to the balance of life (falah) between the worldly purposes (material/financial and social) with the goal of the hereafter (spiritual) that is the pleasure of Allah. Consequently, apart from being an economic institution that runs a dual mission (financial and social intermediation), IMFI also carries out a spiritual mission. It is a manifestation of Islamic values that underlies its overall strategy and purpose. Furthermore, this mission is also reflected in 'spiritual intermediary' activities to educate people and propagate the principles and practices of Sharia, so that they are comprehensively understood and practised by all stakeholders - borrowers and community members (Wediawati \& Setiawati, 2016). This spiritual intermediary must be taken into account so that all activities are performed following the principles of Sharia (Islamic religious law) so that they are not merely impractical concepts.

The finding on the spiritual aspect in choosing microfinance institutions argues counter to the previous research findings by Masyita and Ahmed (2013), where most Muslim borrowers chose conventional institutions and did not consider riba' or other spiritual aspects. In this qualitative research, it is now clear that the different spiritual aspects of clients' preferences in choosing IMFI can be identified. These findings are important to guide community development practitioners or zakat institutions in policymaking and improving the quality of IMFI's services.

In the context of community development programs, a spiritual aspect is considered an essential component in the approach to community development. Practically, the spiritual aspect closely aligns with the faith-based values and principles that underpin community development. The spiritual aspects of zakat-based microfinance, such as silaturahmi and barakah, are closely aligned with the principles of community development such as suppressing the expression of individuals and collective empowerment (Chile \& Simpson, 2004). In this sense, the underpinning principles for community 
development within spirituality is the need to find equilibrium, to ensure that both development processes and outcomes are in harmony socially and sustainably, embrace diversity and picture the future (Ife, 2013). Spiritual aspects in the implementation of zakat-based microfinance as an effective community development program will result in not only the economic development of borrowers but also a strong community supporting actions steeped in and guided by spirituality.

\section{Conclusion}

This research contributes to the advancement of theoretical knowledge on the potential of community development programs funded by zakat. Besides, the empirical findings of this research could serve as a basis for evidence-based policymaking and program reference for both government and private zakat institutions, as well as general community development practitioners in Indonesia and other Muslim countries, to improve the current practice in zakat-based production programs including Islamic microfinance programs funded by zakat.

Future scholarly research should investigate the broader policy of ZCD (zakat community development) in greater depth and evaluate the social impact of the programs not only on the targeted community but also to the wider society, particularly in the contribution of ZCD to achieving SDGs (Sustainable Development Goals) in Indonesia. Apart from that, future research should take into account more diverse community development programs funded by both government and private zakat institutions to provide a broader understanding and thorough analysis of the differentiated community development programs.

This project has significance for community development practitioners working in any community development program funded by zakat. Based on the key findings in this study, the following points are recommended for improving the implementation of zakat-based microfinance of Da'arut Tauhid Peduli, applicable to other government or private zakat institutions in strengthening their community development programs in general.

For further improvement, this research recommends practitioners to First, maximize a bottom-up approach in the planning, implementation, monitoring, and evaluation of the program to empower and foster the community. Secondly, encourage targeted communities to fully participate not only in determining the types of business but also in the decisions concerning the training topics and other capacity building on business skills that are aimed to empower and strengthen the business activities of the borrowers. Thirdly, develop long-term strategic planning for at least 10 years, focusing on longterm outcomes in the transformation of targeted communities from mustahiq to muzzaki. Fourthly, develop business assistance programs, including monitoring and evaluation of the business progress and development of the funded businesses, such as expanding market share, increasing the quality of the product, increasing the added value of the products, and assisting on product legality (such as labeling, product name, and halal certification). Lastly, it is the hope of the researcher that this research is of benefit to both academic and community development practitioners who continue to work for the benefit of communities to whom they dedicate their efforts.

This research is a stepping stone for further research on the effectiveness of zakat disbursement and allocation for production purposes, particularly community development programs.

\section{References}

Ahlin, C., \& Jiang, N. (2008). Can micro-credit bring development? Journal of Development Economics, 86(1), 1-21.

Alim, M. N. (2015). Utilization and accounting of Zakat for productive purposes in Indonesia: A review. ProcediaSocial and Behavioral Sciences, 211, 232-236.

As-Siba'i, M. (1968). Min Rawa'i' Hadharatina. Beirut: Darul Irsyad.

Chile, L. M., \& Simpson, G. (2004). Spirituality and community development: Exploring the link between the individual and the collective. Community Development Journal, 39(4), 318-331.

Chilisa, B., \& Kawulich, B. (2012). Selecting a research approach: Paradigm, methodology, and methods. In C. Wagner, B. Kawulich, \& M. Garner (Eds.), Doing social research: A global context (pp. 51-61). New York: McGraw-Hill Higher Education.

Cull, R., Demirgu“ ç-Kunt, A., \& Morduch, J. (2007). Financial performance and outreach: A global analysis of 
leading microbanks. The Economic Journal, 117(517), F107-F133.

Dooris, M., \& Heritage, Z. (2013). Healthy Cities: facilitating the active participation and empowerment of local people. Journal of Urban Health, 90(1), 74-91.

Dupas, P., \& Robinson, J. (2013). Savings constraints and microenterprise development: Evidence from a field experiment in Kenya. American Economic Journal: Applied Economics, 5(1), 163-192.

Fabry, J. (1980). The Pursuit of Meaning. San Francisco, CA: Harper and Row.

Haines, A. (2009). Asset-based community development. An Introduction to Community Development, $38,48$.

Hasan, S. (2016). Implementing "Zakat"-Based Microfinance in Indonesia. IOSR Journal of Economics and Finance, 7(5), 57-61.

Hassan, M. K., \& Ashraf, A. (2010). An integrated poverty alleviation model combining zakat, awqaf and microfinance. Seventh International Conference-The Tawhidic Epistemology: Zakat and Waqf Economy, 261-281.

Hawwa, S. (2004). Al-Islam. Jakarta: Gema Insani.

Ife, J. (2009). Human rights from below: Achieving rights through community development. Cambridge: Cambridge University Press.

Ife, J. (2013). Community development in an uncertain world. Cambridge: Cambridge University Press.

Isidiho, A. O., \& Sabran, M. S. B. (2016). Evaluating the top-bottom and bottom-up community development approaches: Mixed method approach as an alternative for rural un-educated communities in developing countries. Mediterranean Journal of Social Sciences, 7(4), 266.

Ismail, A. G., \& Possumah, B. T. (2013). A theoretical model for zakat-based Islamic microfinance institutions in reducing poverty. International Research Journal of Finance and Economics, 103, 136-150.

Ismail, A. G., \& Shaikh, S. A. (2017). Where is the Place for Zakat in Sustainable Development Goals? Where is the Place for Zakat in Sustainable Development Goals? Abdul Ghafar Ismail Salman Ahmed Shaikh This version Working Paper no . 4 Citation style: Abdul Ghafar Ismail and Salman Ahmed (No. 4). Bangi.

Kabuya, F. I. (2015). The rotating savings and credit associations (ROSCAs): Unregistered sources of credit in local communities. IOSR Journal of Humanities and Social Science, 20(8), 95-98.

Kasri, R. A. (2016). Effectiveness of zakah targeting in alleviating poverty in Indonesia. Al-Iqtishad: Jurnal Ilmu Ekonomi Syariah, 8(2), 169-186.

Kenny, S., \& Connors, P. (2016). Developing Communities for the Future. Boston: Cengage.

Koperasi Pemberdayaan Ummat. (2020). Jumlah Anggota KOPMU DT. Retrieved November 25, 2020, from Koperasi Pemberdayaan Ummat website: https://kopmudt.com/

Kretzmann, J., \& McKnight, J. P. (1996). Assets-based community development. National Civic Review, 85(4), $23-29$.

Labonte, R. (1997). Community, community development, and the forming of authentic partnerships: Some critical reflections. In M. Minkler (Ed.), Community Organizing and Capacity Building for Health. New Brunswick: Rutgers University Press.

Louis, P., Seret, A., \& Baesens, B. (2013). Financial efficiency and social impact of microfinance institutions using self-organizing maps. World Development, 46, 197-210.

Masyita, D., \& Ahmed, H. (2013). Why is a growth of Islamic microfinance lower than its conventional counterparts in Indonesia? Islamic Economic Studies, 130(607), 1-28.

Navajas, S., Schreiner, M., Meyer, R. L., Gonzalez-Vega, C., \& Rodriguez-Meza, J. (2000). Microcredit and the Poorest of the Poor: Theory and Evidence from Bolivia. World Development, 28(2), 333-346.

Nurzaman, M. S. (2010). Zakat and human development: an empirical analysis on poverty alleviation in Jakarta, indonesia. International Conference on Islamic Economics and Finance, 1-26.

Obaidullah, M., \& Khan, T. (2008). Islamic microfinance development: Challenges and initiatives. Islamic Research $\mathcal{E}$ Training Institute Policy Dialogue Paper, (2).

Permono, S. H. (2005). Formula zakat menuju kesejahteraan sosial. Surabaya: Aulia.

Pickup, F., Beik, I. S., \& Buana, G. K. (2018). Unlocking the potential of zakat and other forms of Islamic finance to achieve the SDGs in Indonesia. Jakarta: BAZNAS Center of Strategic Studies.

Quayes, S. (2012). Depth of outreach and financial sustainability of microfinance institutions. Applied Economics, $44(26), 3421-3433$.

Rashidah, A. R., \& Siti Balqis \& Faisal, D. (2013). Assessing the risk management practices of Islamic banks: Empirical evidence from Malaysia and Pakistan. Journal of Islamic Economics, Banking, and Finance, 9(4), 1131.

Riwajanti, N. I. (2014). Exploring the Role of Islamic Microfinance Institution in Poverty Alleviation Through Microenterprises Development, A Case Study of Islamic Financial Cooperative (BMT) in Indonesia (Special Feature: Socio-Economic Role of Islamic Finance and its Potential. Kyoto Bulletin of Islamic Area Studies, 7, 4966.

Rosadi, A., Effendi, D., \& Busro, B. (2018). The Development of Waqf Management Through Waqf Act in Indonesia 
(Note on Republic of Indonesia Act Number 41 of 2004 regarding Waqf). Madania: Jurnal Kajian Keislaman, 22(1), 1. https://doi.org/10.29300/madania.v22i1.881

Sadeq, A. M. (2002). Waqf, perpetual charity, and poverty alleviation. International Journal of Social Economics, 29(1/2), 135-151.

Sakai, M. (2008). Empowering Islamic Microcredit. Canberra.

Sakai, Minako. (2014). Establishing social justice through financial inclusivity: Islamic propagation by Islamic savings and credit cooperatives in Indonesia. TRaNS: Trans-Regional and-National Studies of Southeast Asia, 2(2), 201-222.

Sanrego, Y. D., \& Antonio, M. S. (2013). The effect of social capital on loan repayment behavior of the poor (a study on Group Lending Model (GLM) application in Islamic microfinance institution). Journal of Indonesian Economy and Business, 28(2), 188-210.

Sari, M. D., Bahari, Z., \& Hamat, Z. (2013). Review of Indonesian zakah management and obstacles. Social Sciences, 2(2), 76-89.

Shaikh, S. A., Ismail, A. G., \& Mohd Shafiai, M. H. (2017). Application of waqf for social and development finance. ISRA International Journal of Islamic Finance, 9(1), 5-14. https://doi.org/10.1108/IJIF-07-2017-002

Sudewo, E. (2004). Manajemen zakat: tinggalkan 15 tradisi terapkan 4 prinsip dasar. Ciputat: Institut Manajemen Zakat.

Sudirman, S. E. A. I. (2011). Implementasi TQM dalam pengelolaan zakat di kota Malang. De Jure: Jurnal Hukum Dan Syar'iah, 3(2).

Suprayitno, E., Abdul Kader, R., \& Harun, A. (2013). The impact of zakat on aggregate consumption in Malaysia. Journal of Islamic Economics, Banking, and Finance, 113(912), 1-24.

Suryanto, A. (2018). Pemberdayaan Zakat: Model Intervensi Kemiskinan Dengan Microfinance Syariah Berbasis Masyarakat DPU DT Jawa Barat, Indonesia. INFERENSI: Jurnal Penelitian Sosial Keagamaan, 12(1), 85-106.

Toriquddin, M. (2015). Pengelolaan zakat produktif: Perspektif maqasid al-syari'ah Ibnu'Asyur. Malang: UIN-Maliki Press.

Wahab, N. A., \& Rahman, A. R. A. (2011). A framework to analyse the efficiency and governance of zakat institutions. Journal of Islamic Accounting and Business Research.

Wediawati, B., Effendi, N., Herwany, A., \& Masyita, D. (2018). Sustainability of Islamic Microfinance in Indonesia: a holistic approach. Academy of Strategic Management Journal, 17(3), 1-14.

Wediawati, B., \& Setiawati, R. (2016). Spiritual intermediation in Islamic microfinance: Evidence from Indonesia. International Conference, Integrated Microfinance Management for Sustainable Community Development (IMM 2016). Atlantis Press.

Yumna, A., \& Clarke, M. (2011). Integrating zakat and Islamic charities with microfinance initiative for the purpose of poverty alleviation in Indonesia. Proceeding 8th International Conference on Islamic Economics and Finance, Center for Islamic Economics and Finance, 1-18.

(C) 2020 by the authors. Submitted for possible open access publication under the terms and conditions of the Creative Commons Attribution (CC BY SA) license (https://creativecommons.org/licenses/by-sa/3.0/). 